\title{
Hak dan Kewajiban Asasi Manusia dalam Perspektif Negara Madinah
}

\section{Oleh:}

M. ALIM

\begin{abstract}
Islamic tenets, especially Al-Qur'an and al-Sunnah, govern various aspects, including the human basic obligations and human rights. Thus, these rights and obligations perform as a part and parcel of Islamic tenets which are harmoniously relate each and others, as has been clearly apparent from the practice during Medina period by the Prophet PBUH. Whereas fiqh,which is considered as a derivation of those two basic sources, opens for differences due to the time and place differences.
\end{abstract}

